\title{
The Effect of Training on Dementia Care among Nurses: A Systematic Review
}

\author{
Sri Mulyani ${ }^{1 *}$, Probosuseno $^{2}$, Intansari Nurjannah $^{1}$ \\ ${ }^{1}$ Department of Mental Health and Community, School of Nursing, Faculty of Medicine, Public Health, and Nursing, Universitas \\ Gadjah Mada, Yogyakarta, Indonesia; ${ }^{2}$ Department of Internal Medicine, Faculty of Medicine, Public Health, and Nursing, \\ Universitas Gadjah Mada, Yogyakarta, Indonesia
}

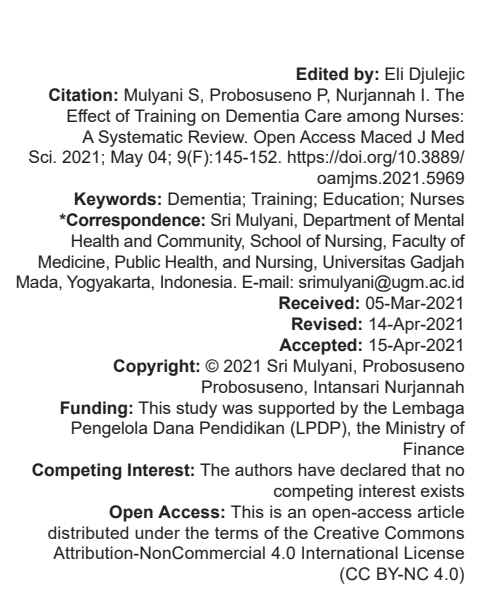

\section{Introduction}

Dementia has become a global concern in the aging population. The need for quality care for dementia has been increasing as the number of patients with dementia is snowballing. The World Alzheimer Report in 2016 stated the number of people with dementia in the world has reached 47 million and it is predicted to be more than 131 million in 2050 [1]. There is no exact number of dementia cases in Indonesia but it is estimated that the number will reach more than 2 million in 2030 [2]. Eminence services in dementia care are essential to increase the quality of life of people with dementia and their caregivers. Nurses as the first line in formal caregivers for dementia patients play a key role in this service. However, nurses' knowledge and skills toward persons with dementia are considered lacking [3]. Thus, dementia training for nurses has emerged as a new trend, especially in developed countries [4], but not in developing countries. Different models and strategies have been used to train nurses and allied health staff to provide better services for patients with dementia. Accordingly, the effect of dementia training on nurses needs to be explored before it can be adapted for nurses in Indonesia. A systematic review by Surr and Gates in 2017 [5] evaluated the training in dementia care using the Kirkpatrick model and the results showed that educational programs in dementia should be relevant to the background of the trainee, support the application in the field, and consider the availability of tools and guidelines to guide practice. However, no specific review on the effect of training for nurses was found. Thus, a specific review on the effect of dementia training on nurses is essential to guide practice toward future training in dementia care.

\section{Methods}

\section{Study design}

This review is guided by Cochrane systematic review book [6] to produce an analysis for the effect of nursing education or training on nurses in dementia care. The writers also used the Preferred 
Reporting Items for Systematic Reviews and MetaAnalysis (PRISMA) [7] to guide the literature search in this review.

\section{Literature search strategy}

Four databases were searched, namely, PubMed, Medline, EBSCO, and ProQuest with the following keywords: Dementia, training, education, and nurses. Google Scholar was also explored to identify papers or reports about the topic in the Indonesian Language since training on dementia in Indonesia was the first aim of this review. However, no paper was found from Indonesia, so the search strategy was changed to English. Medical Subject Heading (MeSH) terms were firstly searched in PubMed before the probing was managed. The keywords being used were dementia (((c"Alzheimer Disease" [MeSH]) OR "Dementia" [MeSH]) OR "Frontotemporal Dementia" [MeSH]) OR "AIDS Dementia Complex" [MeSH]) AND training (("Education" [MeSH] OR "education" [Subheading] OR "Schools, Nursing" [MeSH] OR "Staff Development" [MeSH]) OR ("Vocational Education" [MeSH] OR "Learning" [MeSH])) AND "Nurses" [MeSH] OR "Nursing" [MeSH] OR "nursing" [Subheading] OR "Schools, Nursing" [MeSH] OR "Nursing, Team" [MeSH] OR "Students, Nursing" [MeSH] OR "School Nursing" [MeSH] OR "Geriatric Nursing" [MeSH] OR "Nurse Clinicians" [MeSH] OR "Education, Nursing, Diploma Programs" [MeSH]. Boolean operators and truncation were also utilized. Searching was conducted from February 18 to 20,2019 . Hand searching was also conducted in Google Scholar to find relevant articles. Pointers for searching were generated from the list of references of the selected papers. No limitation on the year of publication was applied, but only peer-reviewed studies published after 1990 were included. However, no risk of bias assessment was applied for the random controlled trials (RCTs). Furthermore, CINAHL as the main source of papers for nurses was not searched due to limitations in access.

\section{Inclusion/exclusion criteria}

PICO format was adapted in this review with the following guide: Population (nurse); Intervention (education or training); Comparison (usual care or other intervention if control group was available); and Outcome (changes on participants).

Inclusion criteria for studies included in this review were the following articles: (1) Experimental study or primary study, (2) the topic was about dementia, (3) written in English or Indonesian language, (4) the participants were nurses or at least some nurses involved, and (5) the outcome measured was on the nurses or allied health providers and not the training. The exclusion criteria were as follows:
The article does not discuss about training or program or education, does not include nurses, and does not relate to dementia.

\section{Search outcome}

The search processes in the four databases resulted in 1277 papers from PubMed, 69 from Medline, 151 papers from EBSCO, and 1226 from ProQuest. The process of the paper selection is presented in Figure 1. The figure was guided by PRISMA flowchart. A total of 2723 papers were identified from this process. There were 19 papers selected from additional resources, namely, Google Scholar. All of these studies were then screened for duplicates which generated in 2039 papers. Title and abstract were next screened from this number and that step generated 155 papers. From 155 abstracts reviewed, 78 were excluded due to unmet inclusion criteria, which resulted 77 papers. Full papers from 77 records were downloaded and assessed based on the eligibility criteria. Finally, 20 articles met the inclusion criteria and were included in the study (Figure 1).

\section{Quality appraisal}

Quality appraisal was managed before the paper was analyzed. Appraisal was based on the study by Surr et al. [4] to evaluate the selected papers. This appraisal was generated from Caldwell et al. [8] and the Critical Appraisal Skills Program checklist. Using the answers: Yes (scored 2), partially (scored 1 ), or no (scored 0), the papers were weighted and categorized as high quality if the total score was 11-14; medium if the total score was 6-10; and low if the total score was 5 or less. The process of quality judgment was managed by the first author and discussed with the other members of the research team.

\section{Data abstraction, analysis, and synthesis}

Data were selected through this paper quality process by the first and second authors. Meanwhile, the development of the review progress and methods was conducted by all of the authors. Routine meetings were conducted to discuss the studies included in the review. Since the data varied in terms of methodology as well as the instruments employed to measure outcomes, we could not conduct a meta-analysis. There was no paper in Indonesian language. Hence, no translations were needed. Papers that only measured the feedback of the participants in the training process were also excluded. The selected papers were then analyzed based on the characteristics of the studies, training conducted (the topic and the length), the outcome 


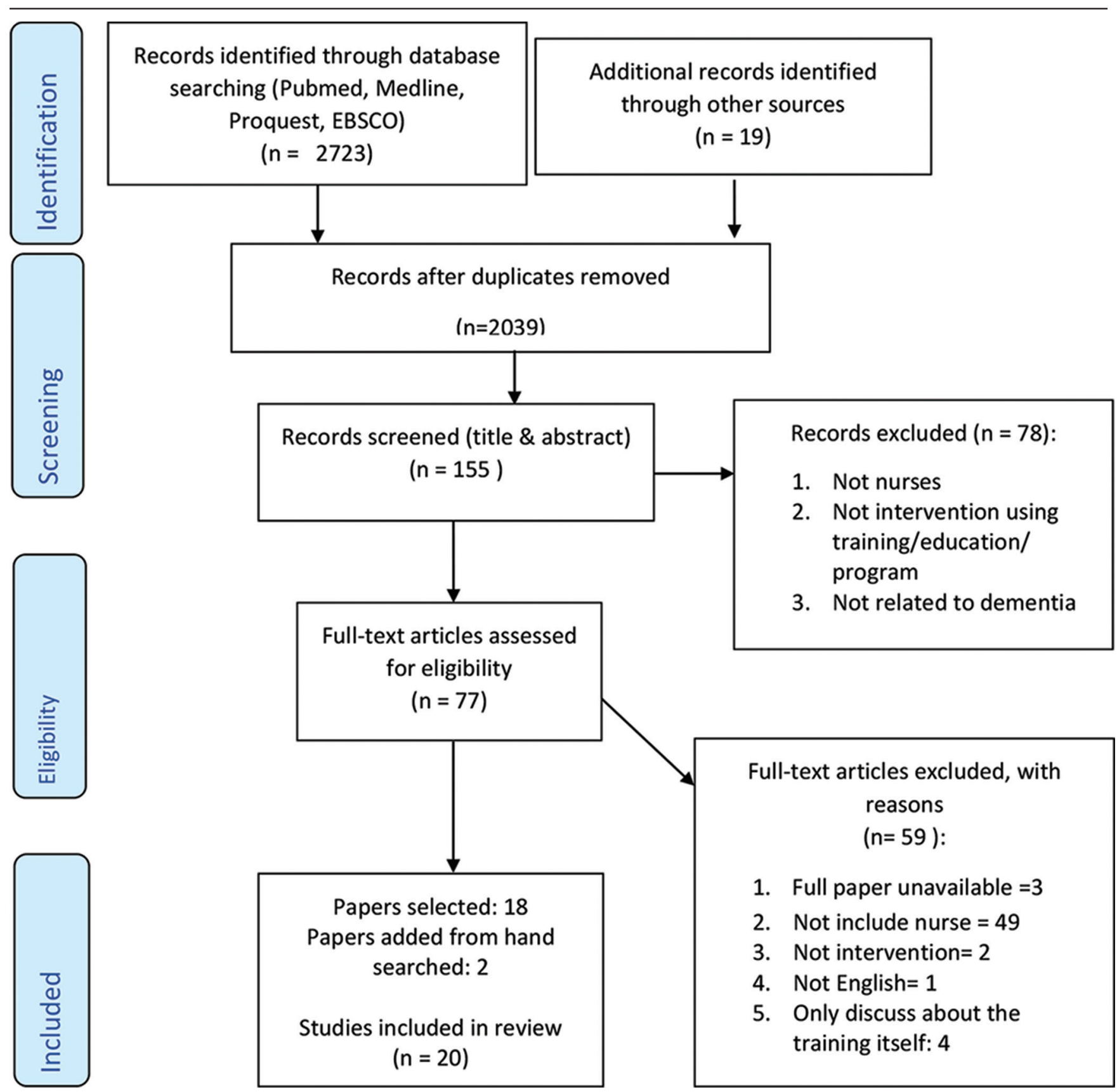

Figure 1: Flow Diagram Following the Preferred Reporting Items for Systematic Reviews and Meta-Analyses Guidelines [7]

measured, and the instrument as well as the time of the measurement.

\section{Results}

There were 20 studies included in this review. They were published between 1996 and 2018. The studies were mostly from the USA and UK while the others were from Australia, China, Scotland, German, Japan, Canada, and Sweden. The interventions were conducted for nurses and staff in the hospital, longterm care, nursing home, residential home, public health centers, and even a training center and a supporter caravan (Table 1). They were da Silva da Silva Serelli et al. [9], Davison et al. [10], Elvish et al. [11], Guzmán et al. [12], Jack-Waugh et al. [13], Kemeny et al. [14], Kuske et al. [15], Matsuda et al. [16], Moyle et al. [17], Palmer and Withee [18], Palmer et al. [19], Peterson et al. [20], Pleasant et al. [21], Schindel Martin et al. [22], Shanley et al. [23], Soderlund et al. [24], Surr et al. [25], Teodorczuk et al. [26], Wang et al. [27], and Wang et al. [28]. All papers were in English. The summary of the quality of the papers is presented in Table 2.

The quality of the papers was mostly high quality $(75 \%$ or 15 papers), medium quality $(20 \%$ or 4 papers), and only $5 \%$ were low quality. There 
Table 1: Summary of included study

\begin{tabular}{|c|c|c|c|c|c|c|c|}
\hline Author(year) & Country & Setting & Methods & Length of training & Outcome measure & Instrument & Time space of measurement \\
\hline $\begin{array}{l}\text { da Silva Serelli } \\
\text { et al.(2017) }\end{array}$ & Brazil & LTC & QN & $\begin{array}{l}\text { 2days at } 2 \mathrm{~h}, 6 \\
\text { individual session }\end{array}$ & $\begin{array}{l}\text { Burden, depression, anxiety, quality } \\
\text { of life }\end{array}$ & $\begin{array}{l}\text { Zarit burden scale, Beck Depression } \\
\text { inventory, Beck anxiety inventory, } \\
\text { SF } 36\end{array}$ & Before training, 12weeks after \\
\hline $\begin{array}{l}\text { Davison } \\
\text { et al.(2007) }\end{array}$ & Australia & $\mathrm{NH}$ & RCT & $\begin{array}{l}8 \text { session, } 60-90 \mathrm{~min} \\
\text { each }\end{array}$ & $\begin{array}{l}\text { Burnout, self-efficacy, nursing } \\
\text { performance }\end{array}$ & $\begin{array}{l}\text { MBI: Maslach Burnout inventory, } \\
\text { self-efficacy of Dementia care, The } \\
\text { scale of nursing performance }\end{array}$ & $\begin{array}{l}\text { Before training, post training, } 6 \\
\text { months after training }\end{array}$ \\
\hline $\begin{array}{l}\text { Elvish } \\
\text { et al.(2018) }\end{array}$ & UK & Hospital & QN & 1day, $6 \mathrm{~h}$ & Confidence, knowledge, belief & $\begin{array}{l}\text { CODE: Confidence in dementia, } \\
\text { KIDE: Knowledge in dementia, } \\
\text { Controllability belief scale }\end{array}$ & Before, after training \\
\hline $\begin{array}{l}\text { Guzman } \\
\text { et al.(2017) }\end{array}$ & UK & $\mathrm{NH}$ and $\mathrm{RH}$ & QN & 3days & $\begin{array}{l}\text { Quality of interaction, care } \\
\text { environment assessment, } \\
\text { competence, attitudes, job } \\
\text { satisfaction }\end{array}$ & $\begin{array}{l}\text { QUIS: Quality of interaction schedule, } \\
\text { SCEAM: Sheffield care environment } \\
\text { assessment matrix; SCIDS sense } \\
\text { of competence in dementia care } \\
\text { staff, ADQ: Approaches to dementia } \\
\text { questionnaire, job satisfaction index }\end{array}$ & $\begin{array}{l}\text { Baseline, before training, after } \\
\text { training, follow-up }\end{array}$ \\
\hline $\begin{array}{l}\text { Jack-Waugh } \\
\text { et al.(2018) }\end{array}$ & Scotland & Hospital & QN & $\begin{array}{l}8 \text { months blended } \\
\text { learning }\end{array}$ & Attitude, knowledge, efficacy & $A D Q, K I D E$, self-efficacy & Before training, after 8 months \\
\hline $\begin{array}{l}\text { Kemeny } \\
\text { et al.(2006) }\end{array}$ & USA & LTC & QN & $\begin{array}{l}\text { Not clear, formal and } \\
\text { informal within 5weeks }\end{array}$ & Knowledge, reaction & $\begin{array}{l}\text { Knowledge scales of PCC; training } \\
\text { reactions questions }\end{array}$ & Before, not clear \\
\hline $\begin{array}{l}\text { Kuske } \\
\text { et al.(2009) }\end{array}$ & Germany & $\mathrm{NH}$ & RCT & $\begin{array}{l}13 \text { session at } 1 \mathrm{~h} \text {, } \\
\text { within } 13 \text { weeks }\end{array}$ & $\begin{array}{l}\text { Knowledge, competencies, } \\
\text { caregiving, burnout, health complaints }\end{array}$ & $\begin{array}{l}\text { GEROLF staff questionnaire, } \\
\text { Penn State Health Caregiving } \\
\text { Questionnaire Maslach Burnout } \\
\text { Inventory, Level of health complaints }\end{array}$ & $\begin{array}{l}\text { Baseline, after training, after } \\
6 \text { months }\end{array}$ \\
\hline $\begin{array}{l}\text { Matsuda } \\
\text { et al. } 2018\end{array}$ & Japan & $\begin{array}{l}\text { Supporter } \\
\text { caravan }\end{array}$ & QN & 2 sessions, at $90 \mathrm{~min}$ & Knowledge, awareness & $\begin{array}{l}\text { DKT-SC, awareness questionnaire } \\
\text { about dementia care }\end{array}$ & Before, after training \\
\hline $\begin{array}{l}\text { Moyle } \\
\text { et al. } 2016\end{array}$ & Australia & LTC & QN & $12 \mathrm{~h}$ & Experience, satisfaction & $\begin{array}{l}\text { SEWDR: Staff experience of working } \\
\text { with demented residents }\end{array}$ & \\
\hline $\begin{array}{l}\text { Palmer and } \\
\text { Withee(1996) }\end{array}$ & USA & $\mathrm{NH}$ & QN & Not clear & $\begin{array}{l}\text { Perception of work and problem } \\
\text { behavior }\end{array}$ & Ryden's perception scale & Before, after training \\
\hline $\begin{array}{l}\text { Palmer } \\
\text { et al.(2014) }\end{array}$ & USA & Hospital & QN & 1day, 5 modules & $\begin{array}{l}\text { Work difficulty, confidence, } \\
\text { knowledge, care issue }\end{array}$ & Explained in other paper & Before training, after 3 months \\
\hline $\begin{array}{l}\text { Peterson } \\
\text { et al.(2002) }\end{array}$ & USA & LTC & QN & $6 \mathrm{~h}$ training & Knowledge, stress, self esteem & $\begin{array}{l}\text { Dementia quiz, FCSI: Formal } \\
\text { caregivers stress index, Reciprocal } \\
\text { Empowerment Scale }\end{array}$ & $\begin{array}{l}\text { Before, after training, after } \\
2 \text { weeks, after 6-8weeks }\end{array}$ \\
\hline $\begin{array}{l}\text { Pleasant } \\
\text { et al.(2017) }\end{array}$ & USA & $\begin{array}{l}\text { Training } \\
\text { center }\end{array}$ & QN & $4 \times$ at $40 \mathrm{~min}$ & Knowledge, competence & $\begin{array}{l}\text { DKQ: Dementia knowledge } \\
\text { questionnaire, SCIDS: Scale of } \\
\text { competence in dementia care staff } \\
\text { scale }\end{array}$ & $\begin{array}{l}\text { Before, after training, after } \\
\text { 30days }\end{array}$ \\
\hline $\begin{array}{l}\text { Schindel } \\
\text { Martin } \\
\text { et al.(2016) }\end{array}$ & Canada & Hospital & $\begin{array}{l}\text { QN and } \\
\text { QL }\end{array}$ & 1day, $7.5 \mathrm{~h}$ & Efficacy, experience & $\begin{array}{l}\text { SBMSEP: Self-perceived behavioral } \\
\text { management self-efficacy profile, } \\
\text { focus group discussion }\end{array}$ & $\begin{array}{l}\text { Before, after training, after } \\
\text { 8weeks }\end{array}$ \\
\hline $\begin{array}{l}\text { Shanley } \\
\text { et al.(1998) }\end{array}$ & Scotland & Hospital & QL & 4days & Experience & 4 research questions & $\begin{array}{l}\text { Before, after training, after } 6 \\
\text { months }\end{array}$ \\
\hline $\begin{array}{l}\text { Soderlund } \\
\text { et al.(2014) }\end{array}$ & Sweden & $\mathrm{NH}$ & MM & $\begin{array}{l}\text { 10days, followed every } \\
\text { month, 1year }\end{array}$ & Working environment & Creative climate questionnaire & Before, after training \\
\hline $\begin{array}{l}\text { Surr } \\
\text { et al.(2016) }\end{array}$ & UK & Hospital & QN & $\begin{array}{l}3.5 \text { days, within } 3-4 \\
\text { months }\end{array}$ & Attitudes, experience, efficacy & $\begin{array}{l}\text { ADQ: Approaches to dementia } \\
\text { questionnaire, SEWDR: Staff } \\
\text { experiences of working with } \\
\text { demented residents questionnaire, } \\
\text { Caring efficacy scale(CES) }\end{array}$ & $\begin{array}{l}\text { Before, after training, after } \\
4-6 \text { weeks, after 3-4 months }\end{array}$ \\
\hline $\begin{array}{l}\text { Teodorczuk } \\
\text { et al.(2014) }\end{array}$ & UK & Hospital & QN, QL & 2days & Confidence, attitude & Comments from participants & Before, after training \\
\hline $\begin{array}{l}\text { Wang et al. } \\
\text { (2017a) }\end{array}$ & China & $\mathrm{PHC}$ & RCT & 3days & Knowledge, attitudes, satisfaction & $\begin{array}{l}\text { ADKS: Alzheimer's disease } \\
\text { knowledge scale, DCAS: Dementia } \\
\text { care attitude scale, ADCQ: Advanced } \\
\text { dementia care questionnaire }\end{array}$ & Before training, after 3 months \\
\hline $\begin{array}{l}\text { Wang et al. } \\
(2017 b)\end{array}$ & China & $\mathrm{PHC}$ & RCT & $2 \mathrm{x}$ at $3 \mathrm{~h}$, applet based & Knowledge, attitudes & $\begin{array}{l}\text { CADKS: Chinese Alzheimer's } \\
\text { disease knowledge scale, CDAS: } \\
\text { Chinese dementia attitudes scale }\end{array}$ & Before training, after 3 months \\
\hline
\end{tabular}

were more quantitative than qualitative studies in the review $(90 \%$ vs. $5 \%)$. Only one employed mixed methods (5\%). Pre-test and post-test were the most commonly used method in the studies and four employed RCT. The setting of the papers was nursing homes or long-term care facilities $(45 \%)$, hospitals $(35 \%)$, and only two studies were conducted in public health centers in China (10\%). The other two studies were conducted in other settings (Table 1).

There are distinctions of training toward dementia in terms of length and content. The length of training varied from 1 full day session up to 4-day trainings which were separated within several weeks or months. The delivery of the training was mostly divided into different modules from one module up to 10 modules which consisted of different topics such as dementia, delirium, confusion, and personcentered care.

There were many aspects measured in the data abstraction. Hence, the outcomes for the nurses and others were then categorized into four domains, namely, cognitive, physical, psychological, and the working performance domains. The cognitive domain consists of knowledge about dementia. The physical category was based on the health complaints from the caregivers and the nurses. The following were the psychological components, including attitude, stress index, self-esteem, control belief, and perception of problems. The last category used in this review was working performance. Working performance was not only related to performance, competency, and efficacy but also job satisfaction, burnout, and working environment after the training (Table 3). 
Table 2: Quality of selected studies

\begin{tabular}{|c|c|c|c|}
\hline Author(year) & High quality & Medium quality & Low quality \\
\hline da Silva Serelli et al. (2017) & $\mathrm{v}$ & & \\
\hline Davison et al. (2007) & $v$ & & \\
\hline Elvish et al. (2018) & $\mathrm{v}$ & & \\
\hline Guzman et al. (2017) & $v$ & & \\
\hline Jack-Waugh et al. 2018 & $\mathrm{v}$ & & \\
\hline Kemeny et al. (2006) & $v$ & & \\
\hline Kuske et al. (2009) & $\mathrm{v}$ & & \\
\hline Matsuda et al. 2018 & $v$ & & \\
\hline Moyle et al. 2016 & $v$ & & \\
\hline Palmer and Withee(1996) & & $v$ & \\
\hline Palmer et al. (2014) & & $\mathrm{v}$ & \\
\hline Peterson et al. (2002) & $v$ & & \\
\hline Pleasant et al. (2017) & $\mathrm{v}$ & & \\
\hline Schindel Martin et al. (2016) & $v$ & & \\
\hline Shanley et al. (1998) & & $v$ & \\
\hline Soderlund et al. (2014) & $v$ & & \\
\hline Surr et al. (2016) & & $v$ & \\
\hline Teodorczuk et al. (2014) & & & $\mathrm{v}$ \\
\hline Wang et al. (2017a) & $\mathrm{v}$ & & \\
\hline Wang et al. (2017b) & $\mathrm{r}$ & & \\
\hline
\end{tabular}

Cognitive domain or knowledge was the most measured outcome in the papers; more than half $(60 \%)$ of the papers reviewed measures of the nurses' knowledge after the training program. Some instruments were used to evaluate the outcome on knowledge before and after the training, namely, ADKS or Alzheimer's Disease Knowledge Scale [27], KIDE or Knowledge in Dementia [11], [13], DKT-SC or Dementia Knowledge Test-Supporter Caravan [16], knowledge scales of PCC or Person-Centered Care [14], and Gerolf staff questionnaire which measure knowledge and competencies related to dementia [15], dementia quiz [20], Dementia Knowledge Questionnaire or DKQ [21], and CADKS or Chinese Alzheimer's Disease Knowledge Scale [28]. The interludes between the pre-test and post-test measurements in the knowledge domain varied from directly after the course, to 2 weeks following the training and up to several months after the course ended. Thus, the results also varied but they were generally positive (Table 3 ).

Table 3: Outcome for nurses training

\begin{tabular}{|c|c|c|}
\hline Effect of training & Results improved & No significant change \\
\hline Cognitive & $\begin{array}{l}\text { Elvish et al.(2018), Jack-Waugh } \\
\text { et al.(2018), Kemeny et al.(2006), } \\
\text { Kuske et al.(2009), Matsuda } \\
\text { et al.(2018), Palmer et al.(2014), } \\
\text { Peterson et al.(2002), Pleasant } \\
\text { et al.(2017), Shanley et al.(1998), } \\
\text { Teodorczuk et al.(2014), Wang } \\
\text { et al.(2017a), Wang et al.(2017b). }\end{array}$ & - \\
\hline $\begin{array}{l}\text { Physical } \\
\text { Psychological }\end{array}$ & $\begin{array}{l}\text { Davison et al.(2007, Jack-Waugh } \\
\text { et al.(2018), Palmer et al.(2014), } \\
\text { Surr et al.(2016), Wang et al. } \\
\text { (2017a), Wang et al.(2017b), } \\
\text { Elvish et al.(2018), Palmer and } \\
\text { Withee(1996). }\end{array}$ & $\begin{array}{l}\text { Kuske et al.(2009). } \\
\text { da Silva Serelli et al.(2017), } \\
\text { Peterson et al.(2002), Guzman } \\
\text { et al.(2017). }\end{array}$ \\
\hline Working performance & $\begin{array}{l}\text { Moyle et al.(2016), Surr et al. } \\
\text { (2016), Jack-Waugh et al.(2018), } \\
\text { Davison et al.(2007), Schindel } \\
\text { Martin et al.(2016), Elvish } \\
\text { et al.,(2018), Matsuda et al.(2018), } \\
\text { Palmer et al.(2014), Guzman } \\
\text { et al.(2017), Kuske et al.(2009), } \\
\text { Pleasant et al.(2017), Teodorczuk } \\
\text { et al.(2014), Wang et al.(2017a), } \\
\text { Soderlund et al.(2014). }\end{array}$ & $\begin{array}{l}\text { Guzman et al.(2017), da Silva } \\
\text { Serelli et al.(2017), Davison } \\
\text { et al.(2007), Kuske etal. } \\
\text { (2009). }\end{array}$ \\
\hline
\end{tabular}

Following nurses' knowledge was the attitude toward persons with dementia. Attitude was included in the psychological domain in this context. Some measurements were used to evaluate nurses' attitude to persons with dementia, namely, ADQ or Approaches to Dementia Questionnaire [12], [13], [25], DCAS or Dementia Care Attitude Scale [27], and Chinese Dementia Attitudes Scale or CDAS [28]. Nurses' attitude toward persons with dementia generally improved after receiving training in dementia care.

Besides their attitude, the review results reveal that the psychological domain was affected by training or education. Other psychological domains consisted of nurses' stress index, self-esteem, control belief, and perceptions of problems. In this domain, stress index and self-esteem of the respondent do not show a significant difference after training/ education was conducted [9], [20]. Nevertheless, the consideration toward behavior that can be constrained was improved after training [11].

Besides nursing attitudes, the next aspect was working performance, which includes nursing confidence, efficacy, and competency. Different measurements were also used, namely, selfefficacy of dementia care, the scale of nursing performance [10], confidence in caring for dementia patient or CODE [11], [19], [26], sense of competence in dementia care staff [29], and self-efficacy [13]. The results mainly show improved nurses' confidence, competency, and efficacy in caring for dementia patients. The improvement was also found in the working environment [24], [29]. However, training did not reduce the workload and caregivers' stress [9], health problems [15], nor staff burnout [10], [15].

\section{Discussion}

This paper aimed to review the effect of training on dementia for nurses in different settings. There are some important results regarding the effect of training for nurses in this area. The results mostly show increases in the knowledge toward dementia care. The results of pre-test and post-test showed that education about dementia can improve nurses' knowledge regarding persons with dementia and related factors in caring for dementia patients such as person-centered care. Even though the length of training was varied, the results were generally positive in increasing the cognitive domain. These results were similar among hospital staff as well as social and allied health professionals [4], [5] that indicated that the cognitive domain was the main outcome measured that generally improved after training. Therefore, training is not the only main source of knowledge, experience in caring for people with dementia [29], [30] and other contact with educational resources as well as joining a support group have also been related to knowledge about dementia [29], [31]. 
Regarding the results in the physical domain, there was no significant effect of training toward health complaints among nurses. This is because many factors affect health complaints, not just training and education in dementia care, such as burden in caregiving [32], [33] as well as their habit and environment [34]. Results regarding how education can increase the health condition were also scarce. Education is usually associated with social factors of health in general [35] rather than specific for nurses. Accordingly, no comparison could be made in this review. However, it has been argued that education can improve caregivers' skills in managing patients with dementia so that it can reduce their burden and at the end increase their psychological health [36].

In the psychological domain, the improvement of the attitude emerged in most papers but still the results were arguable for the stress level, self-esteem, and discernment about problems. It has been argued that the attitude of people is correlated with knowledge; thus, improvement of knowledge is mostly followed by better attitude [4], [37], [38]. In terms of stress level, the content of the training itself did not explicitly state about how to reduce the stress level in caring for persons with dementia [20]. Stress at the working place is defined as a feeling of under pressure when doing a job that can reduce work productivity and health [39]. Nevertheless, stress level is affected by many factors, such as gender, workload, and conflicts with colleagues [40] which were not measured in the studies. This condition is also applicable in terms of self-esteem, suggesting the need for more future research in this area.

Working environment also has unstable results, creating a gap for future study regarding the effect of training and education toward the situation at work. Robust research that includes nurses followed for various lengths of time will be suitable to answer the gap in the studies. Further review should work on this area of follow-up after training to identify the retention of training for nurses.

\section{Review limitation}

The studies included in this review were intended for nurses only. However, not all papers included only nurses as subjects. Furthermore, bias assessment was not made for the RCT articles.

\section{Implication for nursing practice}

Dementia education and training in dementia care are effective in increasing the capability of nurses and staff to improve their quality in caring for people with dementia.

\section{Implication for nursing and health policy}

Training and education in dementia care have been demonstrated to have a positive effect on nurses' competencies. Thus, training can be applied as a method for improving nurses' competency in caring for elderly people, especially those with dementia.

\section{Conclusion}

The effects of dementia training for nurses were varied across settings. Training generally improved the cognitive domain, namely, knowledge regardless of the settings. In addition, various effects on the psychological domain were found. Attitude and problem perceptions were improved while self-esteem and level of stress were not in the long-term care settings. Working performance was also developed as training increased confidence, efficacy, and competencies of nurses unrelated to the location of the training. Training and education in dementia care have been demonstrated to develop nurses' competencies in caring for dementia patients. Hence, specific training in caring for dementia patients can be one of the standards in nursing competencies.

\section{References}

1. Prince $M$, Comas-Herrera $A$, Knapp $M$, Guerchet $M$, Karagiannidou M. World Alzheimer Report 2016: Improving Healthcare for People Living with Dementia: Coverage, Quality and Costs Now and in the Future; 2016.

2. Prince MJ. World Alzheimer Report 2015: The Global Impact of Dementia: An Analysis of Prevalence, Incidence, Cost and Trends: Alzheimer's Disease International; 2015.

3. Thompson R, Heath H. Dignity in Dementia: Transforming General Hospital Care. Summary of Findings from a Survey of Carers and People Living with Dementia. London: Royal College of Nursing; 2011

4. Surr CA, Gates C, Irving D, Oyebode J, Smith SJ, Parveen S, et al. Effective dementia education and training for the health and social care workforce: A systematic review of the literature. Rev Educ Res. 2017;87(5):966-1002. https://doi. org/10.3102/0034654317723305

PMid:28989194

5. Surr CA, Gates C. What works in delivering dementia education or training to hospital staff? A critical synthesis of the evidence. Int J Nurs Stud. 2017;75:172-88. https://doi. org/10.1016/j.ijnurstu.2017.08.002 PMid:28837914

6. Higgins J, Green S. Cochrane Handbook for Systematic Reviews of Intervention. West Sussex: John Willey and Sons Ltd.; 2008.

7. Moher D, Liberati A, Tetzlaff J, Altman DG, Group P. Preferred reporting items for systematic reviews and meta-analyses: The PRISMA statement. PLoS Med. 2009;6(7):e1000097. https://doi.org/10.1371/journal.pmed.1000097 PMid:19621072

8. Caldwell K, Henshaw L, Taylor G. Developing a framework 
for critiquing health research. J Health Soc Environ Issues. 2005;6(1):45-54

9. da Silva Serelli L, Reis RC, Laks J, De Pádua AC, Bottino CM, Caramelli P. Effects of the staff training for assisted living residences protocol for caregivers of older adults with dementia: A pilot study in the Brazilian population. Geriatr Gerontol Int. 2017;17(3):449-55. https://doi.org/10.1111/ ggi. 12742

\section{PMid:26847046}

10. Davison TE, McCabe MP, Visser S, Hudgson C, Buchanan G, George K. Controlled trial of dementia training with a peer support group for aged care staff. Int J Geriatr Psychiatry. 2007;22(9):868-73. https://doi.org/10.1002/gps.1754 PMid: 17191270

11. Elvish R, Burrow S, Cawley R, Harney K, Pilling M, Gregory J, et al. "Getting to know me": The second phase roll-out of a staff training programme for supporting people with dementia in general hospitals. Dementia. 2018;17(1):96-109. https:// doi.org/10.1177/1471301216634926

PMid:26924840

12. Guzmán A, Wenborn J, Swinson T, Orrell M. Evaluation of the ladder to the moon, culture change studio engagement programme staff training: Two quasi-experimental case studies. Int J Older People Nurs. 2017;12(3):e12147. https:// doi.org/10.1111/opn.12147

PMid:28185441

13. Jack-Waugh A, Ritchie L, MacRae R. Assessing the educational impact of the dementia champions programme in Scotland: Implications for evaluating professional dementia education. Nurse Educ Today. 2018;71:205-10. https://doi. org/10.1016/j.nedt.2018.09.019

PMid:30296731

14. Kemeny B, Boettcher IF, DeShon RP, Stevens AB. Using experiential techniques for staff development: liking, learning, and doing. J Gerontol Nurs. 2006;32(8):9-14. https://doi. org/10.3928/00989134-20060801-03

PMid:16915741

15. Kuske B, Luck T, Hanns $\mathrm{S}$, Matschinger $\mathrm{H}$, Angermeyer MC, Behrens J, et al. Training in dementia care: A clusterrandomized controlled trial of a training program for nursing home staff in Germany. Int Psychogeriatr. 2009;21(2):295308. https://doi.org/10.1017/s1041610208008387

PMid:19193252

16. Matsuda $Y$, Hashimoto R, Takemoto S, Yoshioka $Y$, Uehara T, Kawasaki $Y$. Educational benefits for nurses and nursing students of the dementia supporter training program in Japan. PLoS One. 2018;13(7):e0200586. https://doi.org/10.1371/ journal.pone.0200586 PMid:30024922

17. Moyle W, Venturato L, Cooke M, Murfield J, Griffiths S, Hughes $\mathrm{J}$, et al. Evaluating the capabilities model of dementia care: A non-randomized controlled trial exploring resident quality of life and care staff attitudes and experiences. Int Psychogeriatr. 2016;28(7):1091-100. https://doi.org/10.1017/ s1041610216000296 PMid:26960255

18. Palmer AC, Withee BM. Dementia care: Effects of behavioral intervention training on staff perceptions of their work in veterans' nursing home. Geriatr Nurs. 1996;17(3):137-40. https://doi.org/10.1016/s0197-4572(96)80097-8 PMid:8846944

19. Palmer JL, Lach HW, McGillick J, Murphy-White M, Carroll MB, Armstrong JL. The dementia friendly hospital initiative education program for acute care nurses and staff. J Contin Educ Nurs. 2014;45(9):416-24. https://doi. org/10.3928/00220124-20140825-20

PMid:25299008

20. Peterson D, Berg-Weger MS, McGillick J, Schwartz L. Basic care I: The effect of dementia-specific training on certified nursing assistants and other staff. Am J Alzheimers Dis Other Demen. 2002;17(3):154-64. https://doi. org/10.1177/153331750201700309

PMid: 12083345

21. Pleasant ML, Molinari V, Hobday JV, Fazio S, Cullen N Hyer K. An evaluation of the CARES(R) dementia basics program among caregivers. Int Psychogeriatr. 2017;29(1):4556. https://doi.org/10.1017/s1041610216001526 PMid:27692028

22. Martin LS, Gillies L, Coker E, Pizzacalla A, Montemuro M, Suva $G$, et al. An education intervention to enhance staff self-efficacy to provide dementia care in an acute care hospital in Canada: A nonrandomized controlled study. Am J Alzheimers Dis Other Demen. 2016;31(8):664-77. https://doi. org/10.1177/1533317516668574 PMid:27659392

23. Shanley E, McDowell J, Wynne T. Evaluation of a course for charge nurses on caring for people with dementia. J Adv Nurs. 1998;28(3):532-9. https://doi. org/10.1046/j.1365-2648.1998.00714.x PMid:9756220

24. Soderlund M, Norberg A, Hansebo G. Validation method training: Nurses' experiences and ratings of work climate. Int $J$ Older People Nurs. 2014;9(1):79-89. https://doi.org/10.1111/ opn. 12027

PMid:23601158

25. Surr CA, Smith SJ, Crossland J, Robins J. Impact of a person-centred dementia care training programme on hospital staff attitudes, role efficacy and perceptions of caring for people with dementia: A repeated measures study. Int J Nurs Stud. 2016;53:144-51. https://doi.org/10.1016/j. ijnurstu.2015.09.009 PMid:26421910

26. Teodorczuk A, Mukaetova-Ladinska E, Corbett S, Welfare M Learning about the patient: An innovative interprofessional dementia and delirium education programme. Clin Teacher. 2014;11(7):497-502. https://doi.org/10.1111/tct.12203 PMid:25417975

27. Wang F, Xiao LD, Wang K, Li M, Yang Y. Evaluation of a WeChat-based dementia-specific training program for nurses in primary care settings: A randomized controlled trial. Appl Nurs Res. 2017;38:51-9. https://doi.org/10.1016/j. apnr.2017.09.008

PMid:29241520

28. Wang Y, Xiao LD, Ullah S, He GP, De Bellis A. Evaluation of a nurse-led dementia education and knowledge translation programme in primary care: A cluster randomized controlled trial. Nurse Educ Today. 2017;49:1-7. https://doi. org/10.1016/j.nedt.2016.10.016

PMid:27855297

29. Shin JH, Seo HJ, Kim KH, Kim KH, Lee Y. Knowledge about dementia in South Korean nursing students: A cross-sectional survey. BMC Nurs. 2015;14(1):67. https://doi.org/10.1186/ s12912-015-0116-4

PMid:26635508

30. Rust TB, See SK. Knowledge about aging and Alzheimer disease: A comparison of professional caregivers and noncaregivers. Educ Gerontol. 2007;33(4):349-64. https:// doi.org/10.1080/03601270701199065

31. Carpenter BD, Zoller SM, Balsis S, Otilingam PG, Gatz M. Demographic and contextual factors related to 
knowledge about Alzheimer's disease. Am J Alzheimers Disease Other Demen. 2011;26(2):121-6. https://doi. org/10.1177/1533317510394157

PMid:21233137

32. Andrén S, Elmståhl S. Family caregivers' subjective experiences of satisfaction in dementia care: Aspects of burden, subjective health and sense of coherence. Scand J Caring Sci. 2005;19(2):157-68. https://doi. org/10.1111/j.1471-6712.2005.00328.x

PMid:15877641

33. Schulz R, Beach SR. Caregiving as a risk factor for mortality: The Caregiver health effects study. JAMA. 1999;282(23):22159. https://doi.org/10.1001/jama.282.23.2215 PMid:10605972

34. Prescott S, Logan A, Albrecht G, Campbell D, Crane J, Cunsolo $A$, et al. The canmore declaration: Statement of principles for planetary health. Challenges. 2018;9(2):31. https://doi.org/10.3390/challe9020031

35. Viner RM, Ozer EM, Denny S, Marmot M, Resnick M, Fatusi A, et al. Adolescence and the social determinants of health. Lancet. 2012;379(9826):1641-52. https://doi.org/10.1016/ s0140-6736(12)60149-4
PMid:22538179

36. Elif K, Taşkapilioğlu Ö, Bakar M. Caregiver burden in different stages of Alzheimer's disease. Noro Psikiyatr Ars. 2017;54(1):82-6. https://doi.org/10.5152/npa.2017.11304 PMid:28566965

37. Shin $\mathrm{EH}$, Lee HK. The effect the training program on dementia has on the knowledge and attitude of nursing college students towards dementia and attitude towards the caring of the elderly. Med Legal Update. 2019;19(1):357-62. https://doi.org/10.5958/0974-1283.2019.00069.0

38. McCabe M. Dementia education with and without virtual reality (VR) experiences to increase knowledge, build empathy, change attitude and improve care practice. Alzheimers Demen. 2018;14(7):185. https://doi.org/10.1016/j. jalz.2018.06.2017

39. Ganster DC, Schaubroeck J. Work stress and employee health. J Manag. 1991;17(2):235-71.

40. Yunita PI, Saputra IG. Millennial generation in accepting mutations: Impact on work stress and employee performance. Int J Soc Sci Hum. 2019;3(1):102-14. https://doi.org/10.29332/ ijssh.v3n1.268 